\title{
Clinical characteristics and outcomes according to age in lenalidomide-treated patients with RBC transfusion-dependent lower-risk MDS and del(5q)
}

Pierre Fenaux ${ }^{1 *}$, Aristoteles Giagounidis ${ }^{2}$, Dominik Selleslag ${ }^{3}$, Odile Beyne-Rauzy ${ }^{4}$, Moshe Mittelman ${ }^{5}$, Petra Muus ${ }^{6}$, Stephen D. Nimer ${ }^{7}$, Eva Hellström-Lindberg ${ }^{8}$, Bayard L. Powell ${ }^{9}$, Agnes Guerci-Bresler ${ }^{10}$, Mikkael A. Sekeres ${ }^{11}$, H. Joachim Deeg ${ }^{12}$, Consuelo del Cañizo ${ }^{13}$, Peter L. Greenberg ${ }^{14}$, Jamile M. Shammo ${ }^{15}$, Barry Skikne ${ }^{16}$, Xujie $\mathrm{Yu}^{16}$ and Alan F. List ${ }^{17}$

\begin{abstract}
Background: Particularly since the advent of lenalidomide, lower-risk myelodysplastic syndromes (MDS) patients with del $(5 q)$ have been the focus of many studies; however, the impact of age on disease characteristics and response to lenalidomide has not been analyzed.

Methods: We assessed the effect of age on clinical characteristics and outcomes in 286 lenalidomide-treated MDS patients with del $(5 q)$ from two multicenter trials.

Results: A total of 33.9, 34.3, and 31.8\% patients were aged $<65$ years, $\geq 65$ to $<75$ years, and $\geq 75$ years, respectively. Age $<65$ years was associated with less favorable International Prognostic Scoring System (IPSS) risk and additional cytopenias at baseline versus older age groups, significantly lower cytogenetic response rates ( $p=0.022 \mathrm{vs}$. $\geq 65$ to $<75$ years; $p=0.047$ vs. $\geq 75$ years), and higher rates of acute myeloid leukemia (AML) progression (Gray's test, $p=0.013$ ). Lenalidomide was equally well tolerated across age groups, producing consistently high rates of red blood cell transfusion independence $\geq 26$ weeks.
\end{abstract}

Conclusions: Baseline disease characteristics and AML progression appear to be more severe in younger lower-risk MDS patients with del(5q), whereas older age does not seem to compromise the response to lenalidomide.

Trial registration: ClinicalTrials.gov NCT00065156 and NCT00179621

Keywords: Acute myeloid leukemia, del(5q), Lenalidomide, Myelodysplastic syndromes, Age

\section{Background}

Myelodysplastic syndromes (MDS) occur predominantly in patients aged $\geq 60$ years, many of whom have limited treatment options due to comorbidities, functional impairment, or poor medication tolerance $[1,2]$. Studies reporting the effect of age on baseline characteristics and treatment outcomes in MDS are limited and usually involve small patient cohorts [3-5]. This study

\footnotetext{
*Correspondence: pierre.fenaux@aphp.fr

'Service d'Hématologie Séniors, Hôpital Saint-Louis, Université Paris 7 ,

1 Avenue Claude Vellefaux, 75475 Paris, France

Full list of author information is available at the end of the article
}

aims to assess age-related differences in baseline characteristics and outcomes with lenalidomide in red blood cell (RBC) transfusion-dependent patients with del $(5 q)$ included in two multicenter studies (MDS-003 and MDS-004; ClinicalTrials.gov NCT00065156 and NCT00179621) $[6,7]$.

\section{Methods}

The methodology of these studies has been described in detail $[6,7]$. Analyses were carried out on the intentionto-treat population from the MDS-003 and MDS-004 studies. Patients received lenalidomide at one of three 
starting doses and schedules: $5 \mathrm{mg} /$ day, days 1-28 (MDS-004); $10 \mathrm{mg} /$ day, days 1-21 (MDS-003 and MDS004); or $10 \mathrm{mg} /$ day, days 1-28 (MDS-003), all given in 28-day cycles. Response rates and outcomes in lenalidomide-treated patients were analyzed according to age (i.e., $<65$ years, $\geq 65$ to $<75$ years, and $\geq 75$ years). In MDS-004, patients in the placebo or lenalidomide $5 \mathrm{mg} /$ day group without an erythroid response by week 16 or those who experienced loss of erythroid response, could cross over to the lenalidomide 5 or $10 \mathrm{mg} /$ day groups, respectively. Rates of RBC transfusion independence (RBCTI) $\geq 26$ weeks and cytogenetic response (International Working Group 2000 criteria [8]) were compared across age groups using the Tukey test. Duration and time to RBC-TI were estimated using the Kaplan-Meier method, with differences evaluated using the Tukey test. Progression to acute myeloid leukemia (AML) was defined according to French-American-British criteria [9]. Time to AML progression was adjusted for competing risk of death from other causes using Gray's test. Time to AML progression was assessed after lenalidomide treatment failure (defined as lack of RBC-TI $\geq 26$ weeks or relapse after achievement of RBC-TI $\geq 26$ weeks with lenalidomide treatment). Rates of AML progression were analyzed by time since diagnosis; between-group comparisons and overall comparisons were carried out using the Tukey test and log-rank test, respectively. Overall survival (OS) was estimated by the KaplanMeier method and differences evaluated using the log-rank test. OS was also assessed using a Cox proportional hazards model to adjust for differences in life expectancy. Adverse event $(\mathrm{AE})$ severity was graded using the National Cancer Institute Common Terminology Criteria for Adverse Events, version 3.0, and the incidence compared across age groups using Fisher's exact test. Granulocytecolony stimulating factor (G-CSF) use, total lenalidomide dose received, dose reductions, and treatment discontinuation due to AEs were compared across age groups using Fisher's exact test.

\section{Results and discussion}

This pooled analysis included all 286 patients from the MDS-003 and MDS-004 studies who received lenalidomide from study start (Additional file 1: Figure S1). Median patient age was 69 years (range, 36-95); detailed patient characteristics according to age group are provided in Table 1 . Patients were distributed approximately equally across the three age groups: 97 (33.9\%), 98 (34.3\%), and $91(31.8 \%)$ patients were aged $<65$ years, $\geq 65$ to $<75$ years, and $\geq 75$ years, respectively. More patients aged $<65$ years had less favorable International Prognostic Scoring System (IPSS) risk and a higher proportion were Intermediate-1-risk than Low-risk, compared with patients in the $\geq 65$ to $<75$ years ( $p=$ $0.035)$ and $\geq 75$ years $(p=0.099)$ groups. The $<65$ years group had the highest proportion (48.5\%) of patients with two or three cytopenias compared with the $\geq 65$ to $<75$ years $(38.8 \%)$ and $\geq 75$ years $(37.4 \%)$ groups. The higher IPSS categorization and additional cytopenias suggest that the disease was relatively more severe in younger patients. Although the patient population in the two trials was selected (i.e., patients fulfilled a set of inclusion criteria), this finding has not been reported previously to our knowledge.

Patients in the $<65$ years group received a higher median number of cycles of lenalidomide than those in the $\geq 65$ to $<75$ years ( 17 vs. $14 ; p=0.130$ ) and $\geq 75$ years groups ( 17 vs. $10 ; p=0.002$; Table 2 ). The median total lenalidomide dose received was significantly higher in the $<65$ years group (2540.0 mg [range, 65.0-13,730.0]) than in the $\geq 65$ to $<75$ years $(1507.5 \mathrm{mg}$ [range, 30.0 $10,295.0] ; p=0.045)$ and $\geq 75$ years groups $(1070.0 \mathrm{mg}$ [range, 50.0-10,980.0]; $p=0.001$; Table 2).

Rates of RBC-TI $\geq 26$ weeks did not differ among the age groups, nor did the median time to onset of response and duration of response (Table 3). Cytogenetic response rates (major + minor responses) were significantly higher in the $\geq 65$ to $<75$ years $(65.5 \% ; p=0.022)$ and $\geq 75$ years groups $(63.5 \% ; p=0.047)$ than in the $<65$ years group (45.1\%; Table 3 ). The observation that younger patients had lower cytogenetic response rates despite a higher total dose is in contrast to the previously established relationship between lenalidomide dose and cytogenetic response [7, 10]. The lower response rate may have resulted from the relatively more severe disease characteristics in younger patients. In a previous analysis of p53 status in MDS-004, TP53 mutation and high p53 protein expression were identified as significant factors for reduced cytogenetic response in a subset of patients with biopsies available [11]. In the current study, however, no differences in p53 protein overexpression were observed across the three age groups (Table 1), whereas TP53 mutation status could not be assessed.

Lenalidomide was relatively well tolerated in all three age groups, with low rates of treatment discontinuation. More patients discontinued due to AEs in the $\geq 75$ years group compared with the $<65$ years group (19.8 vs. 8.2\%; $p=0.033$; Table 2). The most common grade 3-4 AEs were neutropenia and thrombocytopenia (Table 4). The incidence of grade 3-4 thrombocytopenia was significantly lower in patients aged $<65$ years than in patients aged $\geq 65$ to $<75$ years $(p=0.004)$ and $\geq 75$ years $(p=$ 0.019 ). However, the incidence of grade $3-4$ neutropenia was significantly lower in patients aged $\geq 75$ years than in patients aged $\geq 65$ to $<75$ years $(p=0.041)$. Dose reductions due to thrombocytopenia were more common in the $\geq 75$ years group compared with the $<65$ years group ( $p=0.008$; Table 2$)$. 
Table 1 Baseline characteristics of lenalidomide-treated patients by age group

\begin{tabular}{|c|c|c|c|}
\hline Characteristic & $\begin{array}{l}<65 \text { years } \\
(n=97)^{\mathrm{a}}\end{array}$ & $\begin{array}{l}\geq 65 \text { to }<75 \text { years } \\
(n=98)\end{array}$ & $\begin{array}{l}\geq 75 \text { years } \\
(n=91)\end{array}$ \\
\hline \multicolumn{4}{|l|}{ Age, years } \\
\hline Median & 59 & 69 & 79 \\
\hline Range & $36-64$ & $65-74$ & $75-95$ \\
\hline Female sex, $n(\%)$ & $71(73.2)^{\dagger}$ & $56(57.1)^{\ddagger}$ & $72(79.1)$ \\
\hline \multicolumn{4}{|l|}{ Time since diagnosis, years } \\
\hline Median & 2.4 & 2.7 & 2.5 \\
\hline Range & $0.2-20.7$ & $0.2-14.7$ & $0.1-29.2$ \\
\hline \multicolumn{4}{|l|}{ Creatinine clearance, $\mathrm{ml} / \mathrm{min}$} \\
\hline Median & 117.3 & 88.6 & 55.5 \\
\hline Range & $49.5-259.0$ & $32.3-162.4$ & 18.2-95.6 \\
\hline \multicolumn{4}{|l|}{ ECOG performance status score, ${ }^{\S} n(\%)$} \\
\hline 0 & $17(17.5)$ & $31(31.6)$ & $11(12.1)$ \\
\hline 1 & $23(23.7)$ & $22(22.4)$ & $30(33.0)$ \\
\hline 2 & $3(3.1)$ & $3(3.1)$ & $8(8.8)$ \\
\hline Missing ${ }^{b}$ & $54(55.7)$ & $42(42.9)$ & $42(46.2)$ \\
\hline \multicolumn{4}{|l|}{ IPSS risk, $n(\%)$} \\
\hline Low & $25(30.5)^{* *}$ & $36(43.9)$ & $37(45.7)$ \\
\hline Intermediate-1 & $53(64.6)$ & $37(45.1)$ & $39(48.1)$ \\
\hline Intermediate-2 & $4(4.9)$ & $6(7.3)$ & $5(6.2)$ \\
\hline High & 0 & $3(3.7)$ & 0 \\
\hline Missing & $15(15.5)$ & $16(16.3)$ & $10(11.0)$ \\
\hline \multicolumn{4}{|l|}{ IPSS-R risk, $n$ (\%) } \\
\hline Very low & 0 & $1(1.3)$ & $1(1.3)$ \\
\hline Low & $32(43.2)$ & $30(38.5)$ & $41(54.7)$ \\
\hline Intermediate & $33(44.6)$ & $35(44.9)$ & $22(29.3)$ \\
\hline High & $8(10.8)$ & $8(10.3)$ & $8(10.7)$ \\
\hline Very high & $1(1.4)$ & $4(5.1)$ & $3(4.0)$ \\
\hline Missing & $23(23.7)$ & $20(20.4)$ & $16(17.5)$ \\
\hline \multicolumn{4}{|l|}{ Cytogenetic abnormalities, $n$ (\%) } \\
\hline Isolated del(5q) & $63(64.9)$ & $76(77.6)$ & $61(67.0)$ \\
\hline del(5q) plus 1 additional abnormality & $22(22.7)$ & $11(11.2)$ & $17(18.7)$ \\
\hline del(5q) plus $\geq 2$ additional abnormalities & $8(8.2)$ & $5(5.1)$ & $11(12.1)$ \\
\hline Other or missing data & $4(4.1)$ & $6(6.1)$ & $2(2.2)$ \\
\hline \multicolumn{4}{|l|}{ Number of cytopenias, $n(\%)$} \\
\hline 1 & $50(51.5)$ & $60(61.2)$ & $56(61.5)$ \\
\hline 2 or 3 & $47(48.5)$ & $38(38.8)$ & $34(37.4)$ \\
\hline Missing & 0 & 0 & $1(1.1)^{c}$ \\
\hline \multicolumn{4}{|l|}{ RBC transfusion burden, units/8 weeks } \\
\hline Median & 6 & 6 & 6 \\
\hline Range & $1-15$ & $1-25$ & $1-12$ \\
\hline \multicolumn{4}{|l|}{ Hemoglobin level, g/dl } \\
\hline Median & $7.4^{\ddagger \neq}$ & 7.8 & 7.9 \\
\hline Range & $4.3-10.0$ & $4.0-10.4$ & $3.6-11.8$ \\
\hline
\end{tabular}


Table 1 Baseline characteristics of lenalidomide-treated patients by age group (Continued)

\begin{tabular}{|c|c|c|c|}
\hline \multicolumn{4}{|l|}{ Platelet count, $\times 10^{9} / 1$} \\
\hline$<150$ & $23(23.7)$ & $32(32.7)$ & 29 (31.9) \\
\hline$\geq 150$ & $74(76.3)$ & $66(67.3)$ & $62(68.1)$ \\
\hline \multicolumn{4}{|l|}{ ANC, $\times 10^{9} / 1$} \\
\hline Median & 1.9 & 2.1 & 2.1 \\
\hline Range & $0.2-21.0$ & $0.4-10.3$ & $0.3-20.7$ \\
\hline \multicolumn{4}{|l|}{ Bone marrow blasts, $\%$} \\
\hline Median & 3.0 & 4.0 & 2.0 \\
\hline Range & $0.0-49.0$ & $0.0-19.0$ & $0.0-17.0$ \\
\hline p53 protein overexpression in $\geq 1 \%$ cells, $n / N(\%)$ & $11 / 34(32.4)$ & $8 / 22(36.4)$ & $11 / 29(37.9$ \\
\hline
\end{tabular}

ANC absolute neutrophil count, ECOG Eastern Cooperative Oncology Group, IPSS International Prognostic Scoring System, IPSS-R IPSS-revised, RBC red blood cell ${ }^{\dagger} p=0.024$ vs. $\geq 65$ to $<75$ years; ${ }^{\ddagger} p=0.002$ vs. $\geq 75$ years; ${ }^{8} p=0.001$ for $\geq 65$ to $<75$ years vs. $\geq 75$ years; ${ }^{* *} p=0.035$ vs. $\geq 65$ to $<75$ years; ${ }^{* \neq} p=0.006$ vs. $\geq 65$ to $<75$ years; $p=0.003$ vs. $\geq 75$ years despite intermittent/recent $\mathrm{RBC}$ transfusions

${ }^{a}$ One patient in the $<65$ years group was later diagnosed with acute myeloid leukemia, which had been present at the start of the study

${ }^{\mathrm{b}}$ The ECOG performance status score could only be determined for patients with this information entered into the study database

'The number of cytopenias at baseline could not be determined for one patient due to missing ANC data

G-CSF prophylaxis for neutropenia did not differ significantly across the age groups (data not shown). The lower rates of neutropenia in the $\geq 75$ years group may reflect the reduced total dose of lenalidomide in this age group rather than variations in G-CSF use. Although grade 3-4 neutropenia occurred less frequently in patients aged $\geq 75$ years, infectious episodes were more common (data not shown), a disparity possibly related to the known natural deterioration of the immune response in older individuals [12]. Although thrombocytopenia was one of the most common AEs with lenalidomide, the incidence of grade 3-4 bleeding events remained low across all age groups (data not shown).

The cumulative incidence of AML was significantly lower in the $\geq 75$ years group than in the $\geq 65$ to $<75$ years $(p=0.010)$ and $<65$ years age groups $(p=0.006$; Fig. $1 \mathrm{a})$. Similarly, the incidence of AML after treatment failure was significantly lower in the $\geq 75$ years group than in the $\geq 65$ to $<75$ years $(p=0.006)$ and $<65$ years groups $(p=$ 0.022 ; Fig. 1b). To assess whether this difference could be attributed to differences in duration of MDS between age groups, rates of AML progression were analyzed according

Table 2 Lenalidomide treatment, rates of dose reduction, and discontinuation by age group

\begin{tabular}{|c|c|c|c|}
\hline Lenalidomide & $\begin{array}{l}<65 \text { years } \\
(n=97)^{\mathrm{a}}\end{array}$ & $\begin{array}{l}\geq 65 \text { to }<75 \text { years } \\
(n=98)\end{array}$ & $\begin{array}{l}\geq 75 \text { years } \\
(n=91)\end{array}$ \\
\hline \multicolumn{4}{|l|}{ Total dose, mg } \\
\hline Median & $2540.0^{+}$ & 1507.5 & 1070.0 \\
\hline Range & $65.0-13,730.0$ & $30.0-10,295.0$ & $50.0-10,980.0$ \\
\hline \multicolumn{4}{|l|}{ Number of cycles } \\
\hline Median & $17.0^{\ddagger}$ & 14.0 & 10.0 \\
\hline Range & $1.0-63.0$ & $1.0-64.0$ & $1.0-62.0$ \\
\hline \multicolumn{4}{|l|}{ Dose reductions, $n(\%)$} \\
\hline Neutropenia & $33(34.0)$ & $31(31.6)$ & $23(25.3)$ \\
\hline Thrombocytopenia & $13(13.4)^{\S}$ & $20(20.4)$ & $27(29.7)$ \\
\hline Neutropenia and thrombocytopenia & $6(6.2)$ & $8(8.2)$ & $9(9.9)$ \\
\hline \multicolumn{4}{|l|}{ Treatment discontinuation, $n$ (\%) } \\
\hline Any AEs & $8(8.2)^{n}$ & $17(17.3)$ & $18(19.8)$ \\
\hline Lack of therapeutic effect & $14(14.4)$ & $12(12.2)$ & $10(11.0)$ \\
\hline Death & $2(2.1)$ & $4(4.1)$ & $8(8.8)$ \\
\hline
\end{tabular}

$A E$ adverse event

${ }^{\dagger} p=0.001$ vs. $\geq 75$ years; $p=0.045$ vs. $\geq 65$ to $<75$ years; ${ }^{\ddagger} p=0.002$ vs. $\geq 75$ years; ${ }^{\S} p=0.008$ vs. $\geq 75$ years; ${ }^{\natural} p=0.033$ vs. $\geq 75$ years

${ }^{a}$ One patient in the $<65$ years group was later diagnosed with acute myeloid leukemia, which had been present at the start of the study 
Table 3 RBC-TI $\geq 26$ weeks and cytogenetic response by age group in patients treated with lenalidomide

\begin{tabular}{llll}
\hline Response & $\begin{array}{l}<65 \text { years } \\
(n=97)^{\mathrm{a}}\end{array}$ & $\begin{array}{l}\geq 65 \text { to }<75 \text { years } \\
(n=98)\end{array}$ & $\begin{array}{l}\geq 75 \text { years } \\
(n=91)\end{array}$ \\
\hline RBC-TI $\geq 26$ weeks, $n(\%)$ & $54(55.7)$ & $53(54.1)$ & $41(45.1)$ \\
Median time to RBC-TI $\geq 26$ weeks, weeks (range) & $2.48(1.49-\mathrm{NE})$ & $2.48(1.36-\mathrm{NE})$ & $7.80(2.15-\mathrm{NE})$ \\
$\begin{array}{l}\text { Median duration of RBC-TI } \geq 26 \text { weeks, years (range) } \\
\text { Cytogenetic response, } n / N(\%)\end{array}$ & $4.60(2.31-\mathrm{NE})$ & $3.19(1.74-\mathrm{NE})$ & $2.19(1.20-\mathrm{NE})$ \\
$\quad$ & & $38 / 58(65.5)$ & $33 / 52(63.5)$ \\
\hline
\end{tabular}

NE not estimable, $R B C-T I$ red blood cell transfusion independence

${ }^{\ddagger} p=0.022$ vs. $\geq 65$ to $<75$ years; $p=0.047$ vs. $\geq 75$ years

${ }^{a}$ One patient in the $<65$ years group was later diagnosed with acute myeloid leukemia, which had been present at the start of the study

${ }^{\mathrm{b}}$ Responding patients only

to time since diagnosis. Rates of AML did not differ significantly between patients with a median duration of MDS $\leq 1.5$ years, $>1.5$ to $\leq 3.8$ years, and $>3.8$ years $(p=0.598$; Additional file 2: Table S1).

These findings are consistent with previous long-term data reported from the MDS-003 study, where achievement of cytogenetic response was associated with a lower risk of AML progression in patients with del(5q) treated with lenalidomide [13]. Although none of the individual IPSS variables differed significantly between the age groups (Table 1), a higher proportion of patients aged $<65$ years were classified as Intermediate-1-risk, which may explain their increased risk of AML progression. Higher IPSS categorization and presence of two or three cytopenias at baseline were associated with an increased risk of AML progression in a multivariate model based on data from the MDS-003 study [13]. In a separate analysis of untreated patients with lower-risk MDS, higher rates of AML progression were also seen in patients aged $\leq 65$ years, with 2 -year rates of 6.7 versus $3.0 \%$ in patients aged $>65$ years [14]. These data suggest that younger patients may have an increased risk of AML progression regardless of treatment, which is likely related to the higher-risk disease features of this patient group.

Median OS was 4.87 years ( $95 \%$ confidence interval [CI], 3.58-not estimable), 3.46 years (95\% CI, 2.31-4.27), and 2.40 years $(95 \% \mathrm{CI}, 2.04-3.22)$ in the $<65$ years, $\geq 65$ to $<75$ years, and $\geq 75$ years groups, respectively ( $p=$ 0.001; Fig. 2). OS was not significantly different between age groups when adjusted for life expectancy based on the overall population or when analyzed separately

Table 4 Grade $3-4$ AEs by age group reported in $\geq 5 \%$ of patients

\begin{tabular}{|c|c|c|c|}
\hline$A E, n(\%)$ & $\begin{array}{l}<65 \text { years } \\
(n=97)^{\mathrm{a}}\end{array}$ & $\begin{array}{l}\geq 65 \text { to }<75 \text { years } \\
(n=98)\end{array}$ & $\begin{array}{l}\geq 75 \text { years } \\
(n=91)\end{array}$ \\
\hline Patients with $\geq 1 \mathrm{AE}$ & $91(93.8)$ & $95(96.9)$ & $89(97.8)$ \\
\hline Neutropenia & $73(75.3)$ & $75(76.5)^{\dagger}$ & $57(62.6)$ \\
\hline Thrombocytopenia & $37(38.1)^{\ddagger}$ & $58(59.2)$ & $51(56.0)$ \\
\hline Anemia & $9(9.3)$ & $12(12.2)$ & $14(15.4)$ \\
\hline Leukopenia & $9(9.3)$ & $9(9.2)$ & $15(16.5)$ \\
\hline Pneumonia & $4(4.1)$ & $10(10.2)$ & $9(9.9)$ \\
\hline Fatigue & $1(1.0)^{\S}$ & $8(8.2)$ & $3(3.3)$ \\
\hline Dyspnea & $2(2.1)$ & $4(4.1)$ & $7(7.7)$ \\
\hline Febrile neutropenia & $7(7.2)$ & $5(5.1)$ & $3(3.3)$ \\
\hline Deep vein thrombosis & $2(2.1)$ & $7(7.1)$ & $3(3.3)$ \\
\hline Diarrhea & $6(6.2)$ & $7(7.1)$ & $5(5.5)$ \\
\hline Hypokalemia & $4(4.1)$ & $1(1.0)$ & $6(6.6)$ \\
\hline Cardiac failure congestive & $0^{n}$ & $2(2.0)$ & $5(5.5)$ \\
\hline Fall & $0^{n}$ & $1(1.0)$ & $5(5.5)$ \\
\hline Alanine aminotransferase increased & $5(5.2)$ & $2(2.0)$ & $2(2.2)$ \\
\hline Rash & $4(4.1)$ & $5(5.1)$ & $4(4.4)$ \\
\hline
\end{tabular}

$A E$ adverse event

${ }^{\dagger} p=0.041$ vs. $\geq 75$ years; ${ }^{\ddagger} p=0.004$ vs. $\geq 65$ to $<75$ years; $p=0.019$ vs. $\geq 75$ years; ${ }^{\S} p=0.035$ vs. $\geq 65$ to $<75$ years; $" p=0.025$ vs. $\geq 75$ years

${ }^{a}$ One patient in the $<65$ years group was later diagnosed with acute myeloid leukemia, which had been present at the start of the study 
a

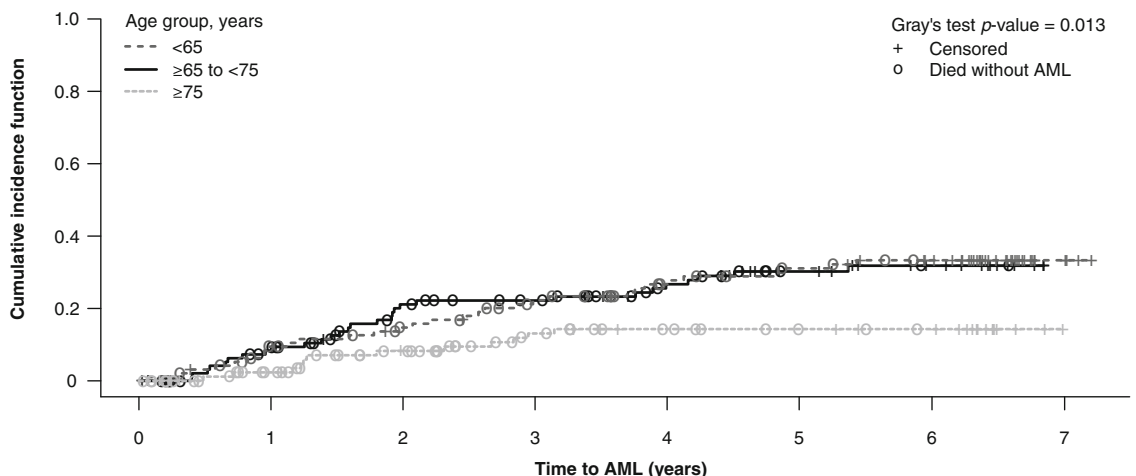

No. patients at risk

\begin{tabular}{|c|c|c|c|c|c|c|c|}
\hline$<65$ & 96 & 81 & 71 & 59 & 47 & 40 & 31 \\
\hline$\geq 65$ to $<75$ & 98 & 81 & 58 & 51 & 35 & 20 & 12 \\
\hline$\geq 75$ & 91 & 68 & 50 & 33 & 23 & 18 & 14 \\
\hline
\end{tabular}

b

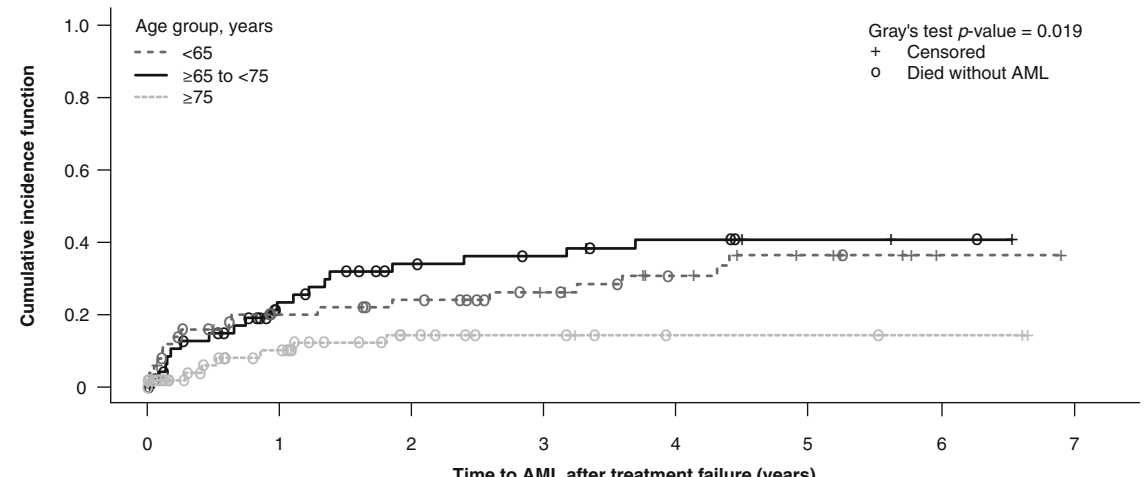

No. patients at risk

$\begin{array}{rlllllll}<65 & 51 & 32 & 28 & 20 & 12 & 7 & 1 \\ \geq 65 \text { to }<75 & 50 & 23 & 13 & 10 & 6 & 3 & 2 \\ \geq 75 & 54 & 24 & 11 & 7 & 3 & 3 & 2\end{array}$

Fig. 1 AML progression by age group in lenalidomide-treated patients (a) or after treatment failure (b). There are 52 patients in the $<65$ years age group, but 1 patient died on day 0 and has been excluded from the analyses. AML acute myeloid leukemia

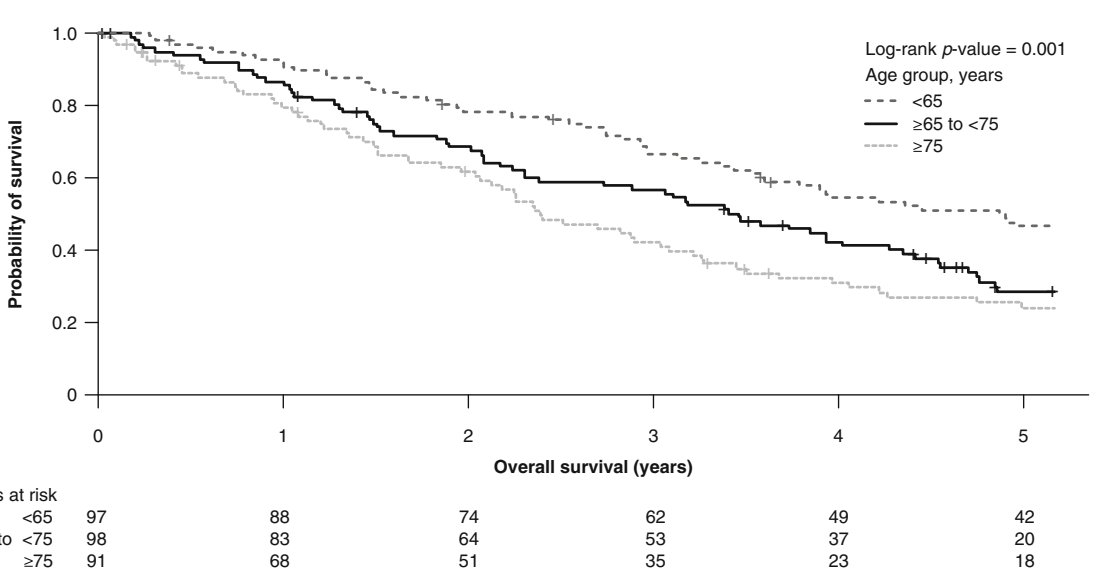

Fig. 2 Overall survival in lenalidomide-treated patients by age group 
according to sex (data not shown). This finding suggests that the shorter OS in the $\geq 75$ years and $\geq 65$ to $<75$ years patient groups likely reflects a higher death rate due to causes other than AML progression. Concomitant disorders are indeed common in this aged population; in particular, infection and the presence of anemia were more frequent in elderly patients. Whereas younger age may be a favorable factor for survival with lenalidomide, the more severe disease characteristics seen in patients aged $<65$ years suggest that this group may benefit from treatment options other than lenalidomide, followed by allogeneic stem cell transplantation in case of primary or secondary lenalidomide treatment failure.

Lower creatinine clearance rates with increasing age (Table 1) result in reduced lenalidomide elimination, ultimately increasing exposure to the drug $[15,16]$. It is possible that differences in drug metabolism and activity at the cellular level may have accounted for some of the apparent age-related differences observed in efficacy outcomes.

These results should be interpreted with caution given certain limitations of our analysis. For example, some mutations such as the TP53 gene mutation and possibly mutations of other genes (i.e., CSNK1A1, ASXL1, TET2) are associated with a poor prognosis in patients with lower-risk MDS with del(5q) [2, 17]. Mutation data were not collected in the MDS-003 and MDS-004 studies, and therefore, it could not be determined if certain mutations were more frequent in the $<65$ years age group. Of note, however, p53 protein overexpression, a validated surrogate marker of TP53 gene mutation, was not influenced by age in the present study.

\section{Conclusions}

In summary, age $<65$ years was associated with poorer disease characteristics at baseline, lower cytogenetic response rates, and higher rates of AML progression than in the older age groups. These findings suggest that resistance to lenalidomide, or relapse after an initial response, may require prompt consideration of allogeneic stem cell transplantation in younger adult patients with lower-risk del(5q) MDS. On the contrary, lenalidomide was equally well tolerated across all age groups, producing consistently high rates of RBC-TI $\geq 26$ weeks, and older age did not appear to compromise response to lenalidomide treatment.

\section{Additional files}

Additional file 1: Figure S1. Study populations in the MDS-003 and MDS-004 studies. Gray shaded boxes: age groups in the present analysis. LEN, lenalidomide. (DOCX $39 \mathrm{~kb}$ )
Additional file 2: Table S1. Cumulative rates of AML progression by age group in lenalidomide-treated patients. AML, acute myeloid leukemia; MDS, myelodysplastic syndromes. (DOCX $14 \mathrm{~kb}$ )

\section{Abbreviations}

AE: Adverse event; AML: Acute myeloid leukemia; ANC: Absolute neutrophil count; ECOG: Eastern Cooperative Oncology Group; G-CSF: Granulocyte-colony stimulating factor; IPSS: International Prognostic Scoring System; IPSS-R: International Prognostic Scoring System-revised; MDS: Myelodysplastic syndromes; NE: Not estimable; OS: Overall survival; RBC: Red blood cells; RBC-T: Red blood cell transfusion independence

\section{Acknowledgements}

Celgene Corporation provided funding for this study. The authors received editorial and writing support provided by Christian Geest, PhD, from Excerpta Medica, supported by Celgene Corporation. The authors had full access to the data and are fully responsible for content and editorial decisions for this manuscript.

\section{Availability of data and materials}

The primary datasets used to generate the dataset for the current study are available in the ClinicalTrials.gov results repository, https:/clinicaltrials.gov/ ct2/show/results/NCT00065156 and https://www.clinicaltrials.gov/ct2/show/ results/NCT00179621.

\section{Authors' contributions}

$\mathrm{PF}$ and $\mathrm{BS}$ designed the research and wrote the manuscript. XY performed the statistical analyses. PF, AG, DS, OB-R, MM, PM, SDN, EH-L, BLP, AG-B, MAS, HJD, CdC, PLG, JMS, and AFL contributed to collection of data. All authors were involved in analyzing and interpreting the data, review and revision of the work, and approval of the final version of the manuscript.

\section{Competing interests}

PF has received honoraria and research funding from Celgene Corporation. AG has received consultancy fees and honoraria from Celgene Corporation. DS has received consultancy fees, honoraria and research funding from Celgene Corporation, Novartis, Amgen and GSK. OB-R has received research funding from Celgene Corporation and Roche. MM has received consultancy fees, honoraria and research funding from Celgene Corporation. PM served on advisory boards for Alexion and Ra Pharma and consultancy for Opsona Therapeutics. SDN has received honoraria from Celgene Corporation. EH-L has received consultancy fees and research funding from Celgene Corporation. AG-B has received consultancy fees from Novartis and honoraria from Celgene Corporation, BMS, Novartis and Amgen. MAS has received research funding from Celgene Corporation. HJD has received research funding from Celgene Corporation. CdC has received consultancy fees and research funding from Celgene Corporation, Janssen-Cilag, Array and Novartis. JMS has received honoraria and research funding from Celgene Corporation. BS and $\mathrm{XY}$ are employees of, and hold equity in Celgene Corporation. AFL has received consultancy fees, honoraria and research funding from Celgene Corporation. BLP and PLG declare that they have no competing interests.

\section{Consent for publication}

Not applicable.

\section{Ethics approval and consent to participate}

The MDS-003 and MDS-004 studies conformed to the Declaration of Helsinki and were approved by individual institutional review boards of all participating institutions. All patients provided written informed consent.

\section{Publisher's Note}

Springer Nature remains neutral with regard to jurisdictional claims in published maps and institutional affiliations.

\section{Author details}

'Service d'Hématologie Séniors, Hôpital Saint-Louis, Université Paris 7 , 1 Avenue Claude Vellefaux, 75475 Paris, France. ${ }^{2}$ Marien Hospital Düsseldorf, Düsseldorf, Germany. ${ }^{3}$ AZ St-Jan BruggeAV, Brugge, Belgium. ${ }^{4}$ Purpan Pavillion de Medecines, Centre Hospitalier Universitaire, Toulouse, France. ${ }^{5}$ Tel Aviv Sourasky Medical Center, Tel Aviv, Israel. ${ }^{6}$ Radboud University 
Medical Centre, Nijmegen, The Netherlands. ${ }^{7}$ Sylvester Comprehensive Cancer Center, University of Miami, Miami, FL, USA. ${ }^{8}$ Karolinska University Hospital, Stockholm, Sweden. ${ }^{9}$ Comprehensive Cancer Center of Wake Forest University, Winston-Salem, NC, USA. ${ }^{10} \mathrm{CHU}$ Brabois, University Center of Medicine, Vandoeuvre, France. ${ }^{11}$ Cleveland Clinic, Cleveland, OH, USA. ${ }^{12}$ Fred Hutchinson Cancer Research Center, Seattle, WA, USA. ${ }^{13}$ Hospital Universitario de Salamanca, Salamanca, Spain. ${ }^{14}$ Stanford Cancer Institute, Stanford, CA, USA. ${ }^{15}$ Rush University Medical Center, Chicago, IL, USA.

${ }^{16}$ Celgene Corporation, Summit, NJ, USA. ${ }^{17} \mathrm{H}$. Lee Moffitt Cancer Center and Research Institute, Tampa, FL, USA.

Received: 3 March 2017 Accepted: 6 June 2017

Published online: 26 June 2017

\section{References}

1. Sanchez JF. Treatment of myelodysplastic syndromes in elderly patients. Adv Ther. 2011;28 Suppl 2:1-9.

2. $\quad$ Adès L, Itzykson R, Fenaux P. Myelodysplastic syndromes. Lancet. 2014;383:2239-52.

3. Fenaux P, Preudhomme C, Hélène Estienne M, Morel P, Laï JL, Gardin C, et al. De novo myelodysplastic syndromes in adults aged 50 or less. A report on 37 cases. Leuk Res. 1990;14:1053-9.

4. Chang KL, O'Donnell MR, Slovak ML, Dagis AC, Arber DA, Niland JC, Forman SJ. Primary myelodysplasia occurring in adults under 50 years old: a clinicopathologic study of 52 patients. Leukemia. 2002;16:623-31.

5. Kuendgen A, Strupp C, Aivado M, Hildebrandt B, Haas R, Gattermann N, Germing U. Myelodysplastic syndromes in patients younger than age 50 . J Clin Oncol. 2006;34:5358-65.

6. List A, Dewald G, Bennett J, Giagounidis A, Raza A, Feldman E, Myelodysplastic Syndrome-003 Study Investigators, et al. Lenalidomide in the myelodysplastic syndrome with chromosome $5 q$ deletion. N Engl J Med. 2006;355:1456-65.

7. Fenaux P, Giagounidis A, Selleslag D, Beyne-Rauzy O, Mufti G, Mittelman M, MDS-004 Lenalidomide del5q Study Group, et al. A randomized phase 3 study of lenalidomide versus placebo in RBC transfusion-dependent patients with Low-/Intermediate-1-risk myelodysplastic syndromes with del5q. Blood. 2011;118:3765-76.

8. Cheson BD, Bennett JM, Kantarjian H, Pinto A, Schiffer CA, Nimer SD, World Health Organization (WHO) international working group, et al. Report of an international working group to standardize response criteria for myelodysplastic syndromes. Blood. 2000;96:3671-4.

9. Bennett JM, Catovsky D, Daniel MT, Flandrin G, Galton DA, Gralnick HR, Sultan C. Proposals for the classification of the myelodysplastic syndromes. Br J Haematol. 1982;51:189-99.

10. Sekeres MA, Swern AS, Giagounidis A, List A, Schlegelberger B, Fenaux P, et al. Association of cytogenetic response (CyR) with RBC transfusionindependence (RBC-TI) and AML-free survival in lenalidomide (LEN)-treated patients (pts) with IPSS Low-/Int-1-risk myelodysplastic syndromes (MDS) with del(5q). Blood. 2013:122. (ASH Annu Meet Abstr):abstract 390. www. bloodjournal.org/content/122/21/390.

11. Saft L, Karimi M, Ghaderi M, Matolcsy A, Mufti GJ, Kulasekararaj A, et al. p53 protein expression independently predicts outcome in patients with lowerrisk myelodysplastic syndromes with del(5q). Haematologica. 2014;99:1041-9.

12. Meyer KC. Aging. Proc Am Thorac Soc. 2005;2:433-9.

13. List AF, Bennett JM, Sekeres MA, Skikne B, Fu T, Shammo JM, MDS-003 Study Investigators, et al. Extended survival and reduced risk of AML progression in erythroid-responsive lenalidomide-treated patients with lower-risk del(5q) MDS. Leukemia. 2014;28:1033-40.

14. Germing U, Lauseker M, Hildebrandt B, Symeonidis A, Cermak J, Fenaux P, et al. Survival, prognostic factors and rates of leukemic transformation in 381 untreated patients with MDS and del(5q): a multicenter study. Leukemia. 2012:26:1286-92

15. Glassock RJ, Winearls C. Ageing and the glomerular filtration rate: truths and consequences. Trans Am Clin Climatol Assoc. 2009;120:419-28.

16. Chen N, Kasserra C, Reyes J, Liu L, Lau H. Single-dose pharmacokinetics of lenalidomide in healthy volunteers: dose proportionality, food effect, and racial sensitivity. Cancer Chemother Pharmacol. 2012;70:717-25.

17. Jädersten M, Saft L, Smith A, Kulasekararaj A, Pomplun S, Göhring G, et al. TP53 mutations in low-risk myelodysplastic syndromes with del(5q) predict disease progression. J Clin Oncol. 2011;29:1971-9.

\section{Submit your next manuscript to BioMed Central and we will help you at every step:}

- We accept pre-submission inquiries

- Our selector tool helps you to find the most relevant journal

- We provide round the clock customer support

- Convenient online submission

- Thorough peer review

- Inclusion in PubMed and all major indexing services

- Maximum visibility for your research

Submit your manuscript at www.biomedcentral.com/submit
) Biomed Central 